\title{
The Effects of Topic Familiarity on Eleventh Graders' Writing Performance
}

\author{
Erly Mulfias Yuli, Sisilia Setiawati Halimi \\ Linguistics Department \\ Universitas Indonesia \\ Depok, Indonesia \\ sshalimi@gmail.com
}

\begin{abstract}
This study investigated the effects of topic familiarity on eleventh graders' writing performance in English as a Foreign Language (EFL) context. The students were assigned to finish two writing tasks with topics that they were familiar with. One of these familiar topics had been experienced by the students, while the other one had not. The purpose was to find out whether topic familiarity would result in the same quality performance in two different writing genres, namely cause-effect and recount. This study also investigated the students' perception of the use of topic familiarity in writing. The study was conducted for about four months and involved 34 eleventh graders and an English teacher. This study used a mixed-method (qualitative and quantitative), and data were collected by using questionnaires, direct observation, and students' writing post-tasks. Students' writing tasks were assessed using an analytic scoring rubric. Findings show that a familiar topic with personal experience significantly affected students' vocabulary production. Furthermore, the students had a positive perception of writing tasks with topic familiarity. Based on this finding, teachers need to be more selective in choosing topics for their students' writing tasks.
\end{abstract}

Keywords: cause-effect text, learning to write, recount text, topic familiarity, writing performance

\section{INTRODUCTION}

Writing skill is one of the priority skills which determines an individual's success in learning a second language, especially English. Harmer (2004) points out that writing is one of the productive skills which can encourage students to focus on language use because it requires them to write what they think. As stated by Meyers (2005), writing is one way to produce language, which is performed naturally when we talk.

Meanwhile, according to Raimes (1983), writing is a skill that is related to the thinking process. This is because writing can help students to familiarize themselves with the grammatical structure, idiomatic expression, and vocabulary which they have learned in class. Besides, writing can also provide an opportunity for the students to explore the language further than they have learned. Writing skills may encourage students to actively use the new language, to express ideas, and to use their eyes, arms, and brains constantly, which is a unique way to support the learning process.

Based on the explanation above, the general definition of writing, as proposed by Harmer (2004), Meyers (2005), and
Raimes (1983), is a process of or skill in expressing ideas and opinions by taking account of linguistic aspects such as diction and grammatical structure.

Nevertheless, teaching students to write in English is not as easy as teaching other skills. Writing is considered as a very complex skill to learn because writing involves a complex cognitive process and consists of at least several main stages, namely planning, translating (the process of expressing ideas using language), reviewing or revising, and monitoring (Tillema, 2012). The fact that there are already many researchers who have agreed and acknowledged that writing tasks have a higher difficulty level has also been pointed out by Harris, Graham, and Mason (2006); Hidi, Berndorff, and Ainley (2002); Graham, Capizzi, Harris, Hebert, and Morphy (2014); and Zumbrunn and Krause (2012).

Even though there have been many studies that have explored the ways to improve writing skills, there are other factors and issues which require further investigation and explanation, namely topic familiarity and level of abstraction of a topic $(\mathrm{Ji}, 2011)$. Topic familiarity is the issue which inspired us to carry out this research because we believe that a familiar topic is an important factor which may motivate students to improve their writing skill.

In his research, McDonough (2018) correlated between two writing tasks and the linguistic knowledge of 67 firstyear college students in Thailand within the context of learning English as a foreign language. McDonough stresses the importance of assigning writing tasks with familiar topics. The assignment results were scored through an analytic rubric. The effectiveness of topic familiarity was measured by assigning student-respondents two writing tasks. The first task involved a familiar topic that was directly related to the students' own experiences or lives, while the second task involved a familiar topic that was not directly related to the students' own experiences or lives. One of the research findings is that the students showed higher performance when they had to write about a topic that is related to their own experiences or lives. Despite this, the overall results of students' writing performance demonstrate that topic familiarity only had a significant impact on the production of texts with subordinate sentences and demanded verb forms.

The next piece of research which has inspired this current research is the one conducted at Shanghai University by Ji (2011). According to $\mathrm{Ji}$, one of the factors which may cause difficulty in writing is the topic's level of abstraction. This research demonstrates that a more focused (specific) topic can 
encourage students to produce a better essay, instead of the more general (abstract) one. This was proven by the fact that the students' task results showed more complex syntax, smoother flow, and more modern, creative, and varied uses of lexical items.

Different from previous research that was conducted in universities, this current research targeted the eleventh-grade senior high school students (hereinafter referred to as the eleventh graders) as beginner writers who had just been taught a couple of text genres in class. One of the most common problems encountered by senior high school students is difficulty in expressing and developing ideas using a foreign language.

Based on this problem, we were interested in carrying out a further investigation into the kinds of strategy which can be used by teachers to assist their students in improving their writing performance. This research is our attempt to solve the problem encountered by most senior high school English teachers and is focused on answering these following research questions.

1. What are the effects of topic familiarity involving an already experienced event on eleventh graders' writing performance in an English class?

2. What is the students' perception of their writing skills after they have accomplished writing tasks about a familiar topic related to an already experienced event?

3. What is the relationship between students' positive perception and their writing performance?

\section{METHOD}

\section{A. Research Context}

This research applied the repeated measures experimental design. This is because the variable data which served as the basis for comparison in this research were the scores of students' writing post-tasks about an already experienced familiar topic and a not-yet experienced familiar topic for each text genre.

\section{B. Data Collection Instruments}

Our research data consisted of the results of students' writing tasks with a familiar topic, both of which had been and had not been experienced by the students (or which is and is not directly related to their lives) in two different genres, namely cause-effect and recount. Besides students' works, the two sets of topic questionnaire were self-developed, while the students' perception questionnaire was adapted from Shadiev, Hwang, and Liu (2018). Quantitative data consisted of the results of the statistical calculations of students' writing task scores using an analytic rubric and a perception questionnaire. Meanwhile, qualitative data consisted of our interpretation of the observation results, topic questionnaire, and our explanation of the effects of topic familiarity on students' writing performance.

\section{Participants}

This research involved 34 eleventh graders and an English teacher at a private school in Bogor as our research subjects. The reason why the eleventh grade was chosen was that it is at this grade where senior high school students, as beginner writers, are given to write cause-effect and recount texts which have been set in the Indonesian national curriculum.

\section{Data Analysis}

To answer our research question about the effects of topic familiarity on the eleventh graders' writing performance, we calculated the total score and the score of every aspect in the scoring rubric which we used to rate students' writing performance. These aspects included task accomplishment, grammatical accuracy (such as the proper use of present tense in cause-effect texts and the proper use of past tense in recount texts), proper production of vocabulary, comprehensibility and critical thinking ability towards the text, and text organization (which includes the coherent and logical arrangement of ideas). Meanwhile, we also calculated the results of the perception questionnaire. Then, the responses were classified into positive and negative perceptions to evaluate the students' perception of the writing tasks. To answer the third research question, after we calculated and classified the total score of the results of the four-responseoption perception questionnaires, we then correlate it with his or her writing task score by using the Pearson ProductMoment (Pearson Correlation).

\section{FINDINGS AND DISCUSSION}

\section{A. The Effects of Topic Familiarity on Writing Performance}

The first topic questionnaire was distributed to 34 eleventh graders as the respondents in this research. However, one student did not receive the first topic questionnaire because of illness. Thus, only 33 sets were returned to us.

Topic questionnaire analysis was carried out to gather familiar topics related to events that had or had not been experienced by the students before receiving the lesson and accomplishing their writing tasks. Analysis of the questionnaire responses resulted in topics that were relevant to the objectives of this research. The results show that, of all participating student-respondents, 97\% had used Instagram, $91 \%$ had experienced the period when the use of cell phones among teenagers increased, $82 \%$ had experienced air pollution, and $70 \%$ had played an online game. Meanwhile, $91 \%$ had never been homeless, approximately $70 \%$ had never witnessed an event of rainforest destruction, and $79 \%$ had never experienced obesity and become a vegetarian. Table I presents the topics which were used in the cause-effect writing task.

TABLE I. TOPICS FOR CAUSE-EFFECT WRITING TASK

\begin{tabular}{|l|l|l|}
\hline \multicolumn{1}{|c|}{$\begin{array}{c}\text { Already experienced cause- } \\
\text { effect topics }\end{array}$} & $\begin{array}{l}\text { Not-yet experienced } \\
\text { cause-effect topics }\end{array}$ & Purpose \\
\hline Playing an online game & Being a vegetarian & practice \\
\hline $\begin{array}{l}\text { Experiencing an increased use of } \\
\text { cell phones among teenagers }\end{array}$ & Being obese & practice \\
\hline Experiencing air pollution & $\begin{array}{l}\text { Witnessing rainforest } \\
\text { destruction }\end{array}$ & practice \\
\hline Using Instagram & Being homeless & post-task \\
\hline
\end{tabular}

Meanwhile, Table II presents a final list of recount topics after we have removed some invalid topics based on the validity test on the recount topic questionnaire responses. This list shows that, of all student-respondents, $94 \%$ had visited a museum, $91 \%$ had once spent their holiday at their grandmother's house, and $88 \%$ had experienced or engaged in an embarrassing event. Meanwhile, $70 \%$ felt that they had never met the Indonesian President when he visited their 
school, $61 \%$ had never been accidentally locked in a restroom, $58 \%$ had never gone to a circus with their classmates after school, and $94 \%$ had never met their favorite actor or actress.

TABLE II. TOPICS FOR RECOUNT WRITING TASK

\begin{tabular}{|l|l|c|}
\hline \multicolumn{1}{|c|}{$\begin{array}{c}\text { Already experienced } \\
\text { recount topics }\end{array}$} & \multicolumn{1}{|c|}{$\begin{array}{c}\text { Not-yet experienced } \\
\text { recount topics }\end{array}$} & Purpose \\
\hline $\begin{array}{l}\text { Spending a holiday at my } \\
\text { grandmother's house }\end{array}$ & Being locked in a restroom & practice \\
\hline Experiencing a bad mood & $\begin{array}{l}\text { Meeting the Indonesian } \\
\text { President when he visited } \\
\text { my school }\end{array}$ & practice \\
\hline $\begin{array}{l}\text { Experiencing an } \\
\text { embarrassing event }\end{array}$ & $\begin{array}{l}\text { Going to a circus with my } \\
\text { classmates after school }\end{array}$ & practice \\
\hline Going to a museum & $\begin{array}{l}\text { Meeting my favorite actor } \\
\text { or actress }\end{array}$ & post-task \\
\hline
\end{tabular}

We utilized the t-test because we wanted to test a hypothesis that says that a familiar topic related to an already experienced event will help students to increase their writing performance than a familiar topic related to a not-yet experienced event. The data in this research were analyzed using the paired sample t-test because we wanted to compare the difference between the values of two different variables in one group. However, because our research data were not normally distributed, we used the Wilcoxon test to calculate the effects. The results of our Wilcoxon test on cause-effect writing task scores are presented in Table III.

TABLE III. RESUlts OF THE WILCOXON TEST ON CAUSE-EFFECT WRITING TASK SCORES

\begin{tabular}{|c|c|c|c|c|c|c|c|}
\hline \multicolumn{7}{|c|}{ Paired Samples Statistics } & \\
\hline & & & Mean & $\mathrm{N}$ & $\begin{array}{c}\text { Std. } \\
\text { Deviation }\end{array}$ & $\begin{array}{l}\text { Std. } \\
\text { Error } \\
\text { Mean }\end{array}$ & \\
\hline \multirow[t]{2}{*}{ Pair 1} & \multicolumn{2}{|c|}{ TACE1 } & 2.9706 & 34 & .93696 & .16069 & \\
\hline & \multicolumn{2}{|c|}{ TACE2 } & 3.0294 & 34 & .96876 & .16614 & \\
\hline \multirow[t]{2}{*}{ Pair 2} & \multicolumn{2}{|c|}{ VocabularyCE1 } & 2.5294 & 34 & .99195 & .17012 & \\
\hline & \multicolumn{2}{|c|}{$\begin{array}{l}\text { VocabularyCE2 } \\
\end{array}$} & 2.1765 & 34 & .96830 & .16606 & \\
\hline \multirow[t]{2}{*}{ Pair 3} & \multicolumn{2}{|c|}{ GrammarCE1 } & 2.4706 & 34 & 1.02204 & .17528 & \\
\hline & \multicolumn{2}{|c|}{ GrammarCE2 } & 2.5588 & 34 & .95952 & .16456 & \\
\hline \multirow[t]{2}{*}{$\begin{array}{l}\text { Pair } 4 \\
\end{array}$} & \multicolumn{2}{|c|}{$\begin{array}{l}\text { ComprehensibilityCE } \\
1\end{array}$} & 2.4706 & 34 & .99195 & .17012 & \\
\hline & \multicolumn{2}{|c|}{$\begin{array}{l}\text { ComprehensibilityCE } \\
2\end{array}$} & 2.5882 & 34 & 1.07640 & .18460 & \\
\hline \multirow[t]{2}{*}{ Pair 5} & \multicolumn{2}{|c|}{ OrganizationCE1 } & 2.5000 & 34 & .92932 & .15938 & \\
\hline & \multicolumn{2}{|c|}{ OrganizationCE2 } & 2.7353 & 34 & .99419 & .17050 & \\
\hline \multicolumn{8}{|c|}{ Test Statistics } \\
\hline \multicolumn{3}{|c|}{\begin{tabular}{l|l} 
& \\
& TACE2 - \\
TACE1
\end{tabular}} & $\begin{array}{l}\text { Vocabula } \\
\text { ryCE2 - } \\
\text { Vocabula } \\
\text { ryCE1 }\end{array}$ & $\begin{array}{l}\text { GrammarC } \\
\text { E2 - } \\
\text { GrammarC } \\
\text { E1 }\end{array}$ & \begin{tabular}{|c|} 
Comprehen \\
sibilityCE2 \\
- \\
Comprehen \\
sibilityCE1
\end{tabular} & \multicolumn{2}{|c|}{$\begin{array}{c}\text { Organization } \\
\text { CE2 - } \\
\text { Organization } \\
\text { CE1 }\end{array}$} \\
\hline $\mathrm{Z}$ & & $-.535^{\mathrm{b}}$ & $-3.464^{c}$ & -.905 & $-.84 \mathrm{C}$ & & $-2.309^{b}$ \\
\hline \multicolumn{2}{|c|}{$\begin{array}{l}\text { Asymp. Sig. } \\
\text { (2-tailed) }\end{array}$} & .593 & .001 & .366 & .39 & & .021 \\
\hline \multicolumn{8}{|c|}{ a. Wilcoxon Signed Ranks Test } \\
\hline b. Base & & tive ranks & & & & & \\
\hline
\end{tabular}

Similar to the paired sample t-test, when we wanted to know the average difference for each aspect in the scoring rubric using the Wilcoxon test, we first had to define our research hypothesis, namely

$\mathrm{H}_{0}=$ there is no average score difference between CE1 and CE2.

$\mathrm{H}_{\mathrm{a}}=$ there is the average score difference between CE1 and CE2.

Our Wilcoxon test results, as presented in Table III, show that only the vocabulary and organization aspects have the Asym. Sig. (2-tailed) value of below 0.05, namely 0.001 for vocabulary and 0.021 for the organization. This demonstrates that there was a significant difference between the vocabulary and organization aspects of the task results in CE1 and CE2. The results of descriptive statistics on the organization aspect show that the CE2 value (2.73) is higher than that of CE1 (2.50), while the results of descriptive statistics on the vocabulary aspect show that the CE1 value (2.52) is higher than that of CE2 (2.17). Because of this, we concluded that in general, a cause-effect writing task with a familiar topic related to an already experienced event did not have any effect on students' writing performance. However, there was a significant improvement in the aspect of vocabulary.

Meanwhile, the results of our Wilcoxon test on recount texts are presented in Table IV.

TABLE IV. RESUlTS OF THE WILCOXON TEST ON RECOUNT WRITING TASK SCORES

\begin{tabular}{|c|c|c|c|c|c|c|c|}
\hline \multicolumn{8}{|c|}{ Paired Samples Statistics } \\
\hline & & & & Mean & $\mathrm{N}$ & $\begin{array}{c}\text { Std. } \\
\text { Deviation }\end{array}$ & $\begin{array}{l}\text { Std. Error } \\
\text { Mean }\end{array}$ \\
\hline \multirow[t]{2}{*}{ Pair 1} & \multicolumn{3}{|c|}{ TARC1 } & 3.0882 & 34 & .86577 & .14848 \\
\hline & \multicolumn{3}{|c|}{ TARC2 } & 3.0000 & 34 & .95346 & .16352 \\
\hline \multirow[t]{2}{*}{ Pair 2} & \multicolumn{3}{|c|}{ VocabularyRC1 } & 2.7353 & 34 & .99419 & .17050 \\
\hline & \multicolumn{3}{|c|}{ VocabularyRC2 } & 2.4706 & 34 & .92884 & .15929 \\
\hline \multirow[t]{2}{*}{ Pair 3} & \multicolumn{3}{|c|}{ GrammarRC1 } & 2.2353 & 34 & 1.01679 & .17438 \\
\hline & \multicolumn{3}{|c|}{ GrammarRC2 } & 2.1176 & 34 & .97746 & .16763 \\
\hline \multirow[t]{2}{*}{ Pair 4} & \multicolumn{3}{|c|}{$\begin{array}{l}\text { ComprehensabilityRC } \\
1\end{array}$} & 2.4412 & 34 & 1.07847 & .18496 \\
\hline & \multicolumn{3}{|c|}{$\begin{array}{l}\text { ComprehensabilityRC } \\
2\end{array}$} & 2.6765 & 34 & 1.09325 & .18749 \\
\hline \multirow[t]{2}{*}{ Pair 5} & \multicolumn{3}{|c|}{ OrganizationRC1 } & 2.5882 & 34 & .92499 & .15864 \\
\hline & \multicolumn{3}{|c|}{ OrganizationRC2 } & 2.7059 & 34 & 1.05971 & .18174 \\
\hline \multicolumn{8}{|c|}{ Test Statistics } \\
\hline \multicolumn{3}{|c|}{$\left|\begin{array}{c} \\
\text { TARC2 } \\
- \\
\text { TARC1 }\end{array}\right|$} & \multicolumn{2}{|c|}{$\begin{array}{c}\text { VocabularyR } \\
\text { C2 - } \\
\text { VocabularyR } \\
\text { C1 }\end{array}$} & $\begin{array}{l}\text { Gramma } \\
\text { rRC2 - } \\
\text { Gramma } \\
\text { rRC1 }\end{array}$ & $\begin{array}{l}\text { Comprehe } \\
\text { nsibilityR } \\
\text { C2 - } \\
\text { Comprehe } \\
\text { nsibilityR } \\
\text { C1 }\end{array}$ & $\begin{array}{c}\text { Organizati } \\
\text { onRC2 - } \\
\text { Organizati } \\
\text { onRC1 }\end{array}$ \\
\hline \multicolumn{2}{|l|}{$\mathrm{Z}$} & $-.905^{\mathrm{b}}$ & \multicolumn{2}{|r|}{$-3.000^{\mathrm{b}}$} & $-1.155^{\mathrm{b}}$ & $-1.685^{\mathrm{c}}$ & $-1.000^{\mathrm{c}}$ \\
\hline \multicolumn{2}{|c|}{$\begin{array}{l}\text { Asymp. Sig. } \\
\text { (2-tailed) }\end{array}$} & .366 & \multicolumn{2}{|r|}{.003} & .248 & .092 & .317 \\
\hline \multicolumn{8}{|c|}{ a. Wilcoxon Signed Ranks Test } \\
\hline \multicolumn{8}{|c|}{ b. Based on positive ranks } \\
\hline c. Base & & ve ranks & & & & & \\
\hline
\end{tabular}

Based on the Wilcoxon test results above, there is a significant difference in the vocabulary aspect, with RC1 
(2.73) being higher than RC2 (2.47). This proves that the use of a familiar topic related to an already experienced event had a significant effect on students' writing performance in terms of vocabulary production in recount texts.

We also improved the writing task reliability by testing the inter-rater reliability to make sure that the scoring process of this writing task was consistent and did not contain any bias. This had to be done because the writing tasks in this research involved open answers. Because of this, the scores which were obtained from inter-rater reliability could be used as supporting information that each of these English writing tasks had a similar range of score, even when the results were scored by different raters.

This inter-rater reliability was calculated by comparing the scores given by an eleventh grade English teacher and those given by researchers. Both raters used an analytic rubric as scoring reference. According to the results of data analysis on the above writing task scores which was processed through inter-rater Cohen Kappa, we concluded that our cause-effect and recount writing tasks with a familiar topic had high reliability because the consistency of the scores is within the range of high agreement between rater 1 (English teacher) and rater 2 (researchers).

Therefore, based on the evaluation results of both text types above, the use of a familiar topic related to an already experienced event had a significant effect on the eleventh graders' vocabulary production. This is in line with Hyland's opinion on the use of a familiar topic that is related to an already experienced event. Hyland (2003) thinks that students who have personal knowledge about a given topic may be able to express their ideas and to produce vocabulary in a better way. This finding also supports McDonough's (2018) which suggests that the use of a familiar topic related to an already experienced event can help improve students' vocabulary production.

Meanwhile, in terms of the organization aspect, the task of writing about a not-yet experienced familiar topic helped students to organize ideas using a better paragraph structure and logical relationships between ideas. This is proven by the fact that the CE2 organization has a higher score than CE1. CE2 organization score had a fairly significant effect on students' writing skills, especially their ability to organize ideas logically. In accordance with our observation notes and students' writing post-task results, students tended to include so many details about their personal experience that they forgot the structural aspect of their CE1 cause-effect writing. Meanwhile, in CE2 they seemed to pay more attention to organization and cause-effect relationship about the topic.

This is in line with Weigle's (2002) explanation in Assessing Writing about the effects of using a familiar topic related to an already experienced event. Weigle also points out that, besides benefits (such as an improvement in students' vocabulary production), a writing task about a familiar topic related to an already experienced event also has some drawbacks. One such drawback is that the students tend to be so emotionally preoccupied with the event they are writing about that they forget about the writing process itself.

Another disadvantage is the test takers may become overly emotionally involved in responding to personal topics, which can result in the writing became more of a release strong emotion and a reliving of experience, with the writing process itself becoming secondary importance. (p.29)[8]

However, based on the results of our observation, we concluded that the teaching and learning process in the class has been performed according to an available approach to teaching writing as proposed by Raimes (1983) which consists of planning, writing a draft, improving or reviewing, giving feedback, and writing the final product. Because of this, the teacher's teaching method did not produce any bias in this research.

\section{B. Students' Perception of the Writing Task}

This perception questionnaire was given to 34 eleventh graders as the respondents in this research. After this perception questionnaire was distributed, 34 sets (100\%) were returned. This activity was carried out to answer the second and third questions about the students' perception of writing tasks with a familiar topic and about the relationship between students' positive perception of writing tasks with a familiar topic and their writing performance. To answer these questions, we first classified the questionnaires based on the students' responses.

During the analysis of the perception questionnaire responses, students' statements were classified into either positive perception or negative perception. Positive perception is deemed to be present when a student feels that writing about a familiar topic related to an already experienced event helps him or her to express and develop ideas and to improve his or her writing performance. Meanwhile, negative perception is deemed to be present when a student feels that even writing about a familiar topic related to an already experienced event cannot help him or her to express and develop ideas and to improve his or her writing performance. In other words, even though they are writing about an event that they have already experienced personally, they still find it difficult to express and develop ideas and to improve their writing performance.

When analyzing this perception questionnaire responses, we classified students' perceptions into two, namely positive perception and negative perception, based on the details of their statements. Positive perception is reflected in the percentages of students who chose "strongly agree" (SA) and "agree" (A) options, while negative perception is reflected in the percentages of students who chose "disagree" (D) and "strongly disagree" (SD) options. Then, we calculated the percentages of students' perceptions using the following formula.

Positive perception $(\%)=\underline{\text { total }(\mathrm{SA})+\operatorname{total}(\mathrm{A})}=\underline{19 \%+59 \%}=78 \%$

30 30

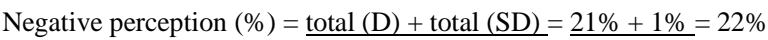

30

30

TABLE V. ClassifICATION OF PERCEPTION BASED ON QUESTIONNAIRE RESPONSES

\begin{tabular}{|l|c|c|}
\hline \multirow{2}{*}{ Details of the Statement } & \multicolumn{2}{|c|}{$\begin{array}{c}\text { Classification of } \\
\text { Perception }\end{array}$} \\
\cline { 2 - 3 } & Positive & Negative \\
\hline $\begin{array}{l}\text { Students' attitude towards a writing } \\
\text { test }\end{array}$ & $78 \%$ & $22 \%$ \\
\hline
\end{tabular}


The result of students' perception of their ability to generate and organize ideas, choose the proper vocabulary, and use the proper grammar, as shown in Table V, was in line with McDonough's (2018) findings.

\section{Relationship between Students' Positive Perception and Their Writing Performance}

At this stage, we identified students' perceptions and correlate it with their writing task results which we had gathered before. The identification was carried out based on this hypothesis: the higher the total perception score is, the more negative the student's perception of this writing strategy is; the lower the total perception score is, the more positive the student's perception of this writing strategy is. This is because we have assigned score 1 to "strongly agree" (SA), all the way up to score 4 to "strongly disagree" (SD).

To correlate the perception scores with students' writing performance scores, we used the Pearson Product-Moment (Bivariate Correlation).

TABLE VI. CORRELATIONS BETWEEN PERCEPTION QUESTIONNAIRE RESPONSES AND EACH SCORED ASPECT

\begin{tabular}{|c|c|c|c|c|c|c|c|}
\hline & & & & relation & & & \\
\hline To & & & $\begin{array}{l}\mathrm{T} \\
\mathrm{A}\end{array}$ & $\begin{array}{l}\text { Voca } \\
\text { bular }\end{array}$ & $\begin{array}{c}\text { Gra } \\
\text { mma }\end{array}$ & $\begin{array}{l}\text { Compreh } \\
\text { ensibility }\end{array}$ & $\begin{array}{l}\text { Organi } \\
\text { zation }\end{array}$ \\
\hline $\mathrm{C}$ & Perce & $\begin{array}{l}\text { Pearson } \\
\text { Correlatio } \\
\mathrm{n}\end{array}$ & $\begin{array}{r}.38 \\
9^{*}\end{array}$ & $.397^{*}$ & .412 & $.344^{*}$ & $.339^{*}$ \\
\hline E & ption & $\begin{array}{l}\text { Sig. (2- } \\
\text { tailed) }\end{array}$ & $\begin{array}{r}0.0 \\
23\end{array}$ & 0.02 & $\begin{array}{r}0.01 \\
5\end{array}$ & 0.047 & 0.05 \\
\hline & & $\mathrm{N}$ & 34 & 34 & 34 & 34 & 34 \\
\hline$R$ & & $\begin{array}{l}\text { Pearson } \\
\text { Correlatio } \\
n\end{array}$ & $\begin{array}{l}.51 \\
6^{* *}\end{array}$ & $.348^{*}$ & $\begin{array}{r}.534 \\
* *\end{array}$ & $.454^{* *}$ & $.488^{* *}$ \\
\hline $\mathrm{C}$ & ption & $\begin{array}{l}\text { Sig. (2- } \\
\text { tailed) }\end{array}$ & $\begin{array}{r}0.0 \\
02\end{array}$ & 0.044 & $\begin{array}{r}0.00 \\
1\end{array}$ & 0.007 & 0.003 \\
\hline & & $\mathrm{N}$ & 34 & 34 & 34 & 34 & 34 \\
\hline & relati & s significe & & $.05 \mathrm{lev}$ & (2-tai & & \\
\hline
\end{tabular}

Our correlation test results, as shown in Table VI, demonstrate that there is a positive correlation between students' perception and CE and RC values. In other words, the higher a student's perception questionnaire score is, the higher the student's CE and RC writing task score is. It can also be said that, even though many students got high scores, they had a negative perception of writing tasks with a familiar topic related to an already experienced event. On the other hand, students who had a positive perception of such tasks did not get a reasonably high writing task score. Therefore, it can be concluded that students' perception, in this case, the positive one, was not related to their writing performance.

Besides that, we also calculated the correlation between the students' perception of their writing task results and each of the scored aspects. Table VI demonstrates that, even though there is a positive correlation between students' perception of their writing task results and all scored aspects, three aspects have a weak correlation and two aspects have a moderate correlation. Moderate correlation can be observed in the task accomplishment and grammar aspects. This proves that students still found it difficult to carry out their writing tasks, especially when it came to the aspect of grammar.

\section{CONCLUSION}

Based on our research results, we concluded that writing tasks with a familiar topic related to an already experienced event can help to significantly improve students' writing performance in terms of vocabulary production, both in causeeffect and recount texts. Besides that, this research also generated a new finding of the effects of topic selection on students' performance: a familiar topic related to a not-yet experienced event can significantly improve students' writing performance in terms of organization of ideas. According to the results of our perception questionnaire analysis, students had a positive perception of writing tasks with a familiar topic related to an already experienced event. The students said that such writing tasks made it easier for them to express and develop their ideas and to choose the right words. Nevertheless, we also found a positive correlation between students' positive perception and their writing task scores. This means that the students' positive perception was not related to the quality of their writing.

In accordance with our research findings, we suggest that teachers be more selective in choosing the topics for their students' writing tasks. Teachers should find topics that are relevant to or strongly related to the students' lives and personal experiences so that the topic becomes more interesting and can motivate students to write. Besides that, topics that are relevant to students' lives can make it easier for them to express and develop their ideas because such ideas come directly from their background knowledge. Our new finding of the organization aspect in cause-effect texts can serve as a basis for future research which investigates the reason why higher scores were generated when the students were required to write about a familiar topic related to a notyet experienced event.

\section{ACKNOWLEDGMENT}

We would like to thank the Directorate of research and Community Engagement, Universitas Indonesia for the PITMA 2019 research grant that we have received.

\section{REFERENCES}

Graham, S., Capizzi, A. M., Harris, K. R., Hebert, M., \& Morphy, P. (2014). Teaching writing to middle school students: A national survey. Reading and Writing, 27(6), 1015-1042. doi: 10.1007/s11145-0139495-7.

Harmer, J. (2004). How to teach writing. Essex: Pearson Education Limited.

Harris, K. R., Graham, S., \& Mason, L. H. (2006). Improving the writing, knowledge, and motivation of struggling young writers: Effects of selfregulated strategy development with and without peer support. American Educational Research Journal, 43(2), 295-340. doi: 10.3102/00028312043002295.

Hidi, S., Berndorff, D., \& Ainley, M. (2002). Children's argument writing, interest and self-efficacy: An intervention study. Learning \& Instruction, 12(4), 429-446. doi: 10.1016/S0959-4752(01)00009-3.

Hyland, K. (2003). Second Language Writing. New York: Cambridge University Press.

Ji, X. (2011). Topic effect on writing performance: What do students and their writings tells us? The Journal of Asia TEFL, 8(1), 23-38.

McDonough, K. (2018). Identifying effective writing tasks for use in EFL write-to-learn language contexts. The Language Learning Journal, 15(4), 1-12. doi: 10.1080/09571736.2018.1465990. 
Meyers, A. (2005). Gateways to academic writing: Effective sentences, paragraphs, and essays. New York: Longman.

Raimes, A. (1983). Techniques in teaching writing. New York: Oxford University Press.

Shadiev, R., Hwang, W. Y., \& Liu, T. Y. (2018). Investigating the effectiveness of a learning activity supported by a mobile multimedia learning system to enhance autonomous EFL learning in authentic contexts. Education Tech Research Dev, 66, 893-912. doi: 10.1007/s11423-018-9590-1.
Tillema, M. (2012). Writing in first and second language: Empirical studies on text quality and writing processes. (Unpublished Doctoral Dissertation). Universiteit Utrecht, Utrecht, Netherlands.

Weigle, S. C. (2002). Assessing Writing. Cambridge: Cambridge University Press.

Zumbrunn, S., \& Krause, K. (2012). Conversations with leaders: Principles of effective writing instruction. The Reading Teacher, 65(5), 346-353. doi: 10.1002/TRTR.01053. 